\title{
Structure identification, antitumor activity and mechanisms of a novel polysaccharide from Ramaria flaccida (Fr.) Quél
}

\author{
MINGMING DONG ${ }^{1^{*}}$, YILING HOU ${ }^{1 *}$ and XIANG DING ${ }^{2}$ \\ ${ }^{1}$ Key Laboratory of Southwest China Wildlife Resources Conservation, College of Life Sciences; \\ ${ }^{2}$ College of Environmental Science and Engineering, China West Normal University, Nanchong, Sichuan 637009, P.R. China
}

Received November 27, 2019; Accepted May 13, 2020

DOI: $10.3892 / \mathrm{ol} .2020 .11761$

\begin{abstract}
It is an important aspect of current cancer research to search for effective and low-toxicity anticancer drugs and adjuvants. Polysaccharides, as immunomodulators, can improve the immune function of the body, kill tumor cells directly and prevent tumor development by increasing the resistance of the body to carcinogenic factors. The aim of the present study was to identify natural polysaccharide compounds with novel structure and antitumor activity via the separation and analysis of polysaccharide components from Ramaria flaccida (Fr.) Quél. (RF-1). In the present study, high-performance gel permeation chromatography, gas chromatography-mass spectrometry and nuclear magnetic resonance were used to identify the structure of polysaccharides from RF-1. Subsequently, the antitumor activity and mechanism of RF-1 were studied by establishing an in vivo S180 tumor model, and by using Illumina sequencing technology and enzyme-linked immunosorbent assay (ELISA). The present results revealed that the average molecular weight of RF-1 was 17,093 Da and that RF-1 was composed of the monosaccharides glucose and galactose, with a 2:1 ratio. The main chain of RF-1 consisted of $(1 \rightarrow 6,2)-\alpha$-D-galactopyranose and $(1 \rightarrow 6,4)$ $\alpha$-D-glucopyranose. One of the branched chains was linked to $4-\mathrm{O}$ of the main glucose chain by $(1 \rightarrow 6)-\alpha-\mathrm{D}$-glucopyranose and next linked by one $(\rightarrow 4)-\beta$-D-glucopyranose. The other two branched chains were both linked to $2-\mathrm{O}$ of the main glucose chain by one $(\rightarrow 4)-\beta$-D-glucopyranose. In addition, $\mathrm{RF}-1$ inhibited the growth of $\mathrm{S} 180$ tumors in vivo. When the concentration of RF-1 was $20 \mathrm{mg} / \mathrm{kg}$, the inhibition rate of S180 tumors in mice was $48.4 \%$. Compared with the
\end{abstract}

Correspondence to: Professor Xiang Ding, College of Environmental Science and Engineering, China West Normal University, 1 Shida Road, Nanchong, Sichuan 637009, P.R. China E-mail: biostart8083@126.com

*Contributed equally

Key words: Ramaria flaccida (Fr.) Quél., polysaccharides, structure, antitumor activity, transcriptome, differentially expressed genes blank control group, 1,971 differentially expressed genes were identified, of which 818 were upregulated and 1,153 were downregulated in the RF-1 group. A Gene Ontology enrichment analysis generated 47,091 assignments to biological processes, 5,250 assignments to cellular components, and 6,466 assignments to molecular functions. Kyoto Encyclopedia of Genes and Genomes pathway enrichment analysis revealed that the Wnt and MAPK signaling pathways were significantly enriched. The number of differentially annotated genes in these two pathways was 19 and 33, respectively. Additionally, ELISA results revealed that the protein levels of interleukin (IL)-1 $\beta$, IL-6, vascular endothelial growth factor (VEGF) and VEGF receptor in the RF-1 group were significantly downregulated compared with the $\mathrm{S} 180$ blank control group $(\mathrm{P}<0.01)$.

\section{Introduction}

Edible fungi polysaccharides are a type of active substances that are separated from fruiting bodies, mycelia and fermentation broth of edible and medicinal fungi that serve a role in cell metabolism $(1,2)$. They are natural macromolecule polymers composed of $>10$ monosaccharides linked by glycoside bonds (3). Previous studies have demonstrated that polysaccharides from edible fungi can have biological activities, such as having antitumor, anti-viral, anti-oxidation and anti-ageing functions, regulating the immune function, improving myocardial protection and lowering blood sugar and lipids (4-7).

Structure determines function, and therefore the complexity of the polysaccharide structure poses a difficulty in research. Polysaccharides can vary in the arrangement of monosaccharides, which can be linked in numerous ways to form polysaccharides. Additionally, there can be multiple branches at different locations in the main polysaccharide chain, as well as different monosaccharide compositions and connection types on branches (8). Furthermore, monosaccharides can form high-level spatial structures (9). Therefore, it is of great scientific importance to analyze the structure and activity of polysaccharides.

Ramaria flaccida (Fr.) Quél., also known as broom fungi, is a common fungus, belongs to the Ramariaceae family. The fruiting bodies are of medium size (height, $2-5 \mathrm{~cm}$; branch thickness, 0.3-0.5 cm), with branches forming dense twigs; 
stems are short, usually branched from the base of the stipe, and the fungi grow on the deciduous layer or dead branches of the ground in broad-leaved or coniferous forests in summer and autumn (10). The fungi contain a variety of carbohydrates, amino acids and trace elements that are beneficial to the human body (7). However, research on Ramaria flaccida (Fr.) Quél. has been limited to its resource investigation, identification and classification, liquid culture, extraction technology of macromolecule substances and chemical composition $(11,12)$. The fruiting bodies of Ramaria flaccida (Fr.) Quél are edible; additionally, this fungus can be used as an indicator of air pollution, which has a great economic value $(11,12)$. To the best of our knowledge, the structure analysis and antitumor activity of pure polysaccharides from Ramaria flaccida (Fr.) Quél. have not yet been reported.

In order to identify a novel polysaccharide with good antitumor activity, in the present study purified polysaccharides were obtained from Ramaria flaccida $(F r$.) Quél. (RF-1) by hot-water extraction, the Sevage method, and by diethylaminoethyl (DEAE)-52 cellulose chromatography. High-performance gel permeation chromatography (HPGPC), gas chromatography-mass spectrometry (GC-MS) and nuclear magnetic resonance (NMR) were used to identify the polysaccharide structure. The antitumor activity of RF-1 was investigated by establishing an in vivo S180 tumor model. The transcriptomes of tumor tissues in the blank control group and RF-1 group were sequenced using Illumina sequencing. The present study may help to exploit and utilize the polysaccharide resources from Ramaria flaccida (Fr.) Quél., and may provide a theoretical reference for further study of its antitumor mechanism and economic value.

\section{Materials and methods}

Materials. The fruiting bodies of Ramaria flaccida (Fr.) Quél. were collected from the Xiaojin County, Aba Tibetan and Qiang Autonomous Prefecture, Sichuan, China, for which specific permission was not required due to it being an open village in China. The field studies did not involve endangered or protected species, since the endangered or protected species protection zone was not accessed for sampling. DEAE-52 Cellulose Column was purchased from Shenyang Shengxing Biotechnology Co., Ltd. RIPA lysis buffer was purchased from Beyotime Institute of Biotechnology. Anhydrous sodium sulfate and potassium bromide were purchased from Sangon Biotech Co., Ltd. Trifluoroacetic acid, acetonitrile, methanol, iodomethane, chloroform and anhydrous pyridine were purchased from Xuzhou Maoyang Chemical Co., Ltd. The experimental reagents were all analytical reagents. Tumor necrosis factor (TNF) $\alpha$, interleukin (IL)-6, IL-1 $\beta$, vascular endothelial growth factor (VEGF) and VEGF receptor (VEGFR) enzyme-linked immunosorbent assay (ELISA) kits were purchased from R\&D Systems China Co., Ltd. The signaling pathways were drawn using Pathway Builder Tool 2.0 (http://www.proteinlounge.com/PathwayBuilder.aspx).

Isolation and extraction of polysaccharides from Ramaria flaccida (Fr.) Quél. The fruiting bodies of Ramaria flaccida (Fr.) Quél. were accurately weighed at $500 \mathrm{~g}$. After being dried and crushed, distilled water was added to the fruiting body powder at a ratio of $1: 30(\mathrm{~g} / \mathrm{ml})$ and boiled for $3 \mathrm{~h}$ in a constant temperature water bath at $100^{\circ} \mathrm{C}$. After being centrifuged at $16,670 \mathrm{x}$ g for $15 \mathrm{~min}$ at $4^{\circ} \mathrm{C}$., the supernatant was collected and concentrated to $200 \mathrm{ml}$ (13). Subsequently, the proteins in the concentrated supernatant were removed by the Sevage method (14). Finally, 3 times the volume of anhydrous ethanol was added and stirred to produce flocculent precipitates. The crude polysaccharide of Ramaria flaccida (Fr.) Quél was obtained by precipitation and dissolved in $200 \mathrm{ml}$ distilled water. A total of $3 \mathrm{ml}$ crude polysaccharide solution was added to a DEAE-52 cellulose column, and $150 \mathrm{ml}$ distilled water was used at a flow rate of $5 \mathrm{ml} / \mathrm{min}$ to obtain the eluent. The eluent was concentrated to $5 \mathrm{ml}$ and subsequently lyophilized, after removing small-molecule compounds using dialysis bags (15). Finally, the purified polysaccharide of Ramaria flaccida ( Fr.) Quél was obtained and named RF-1.

Determination of the molecular weight of RF-1 using $H P G P C$. The molecular weight of RF-1 was determined using HPGPC, as previously described (16). The data are analyzed using the GPC software (Agilent Empower Pro GPC Data Analysis Software for Agilent ChemStation; version B.01.02; Agilent Technologies Inc.). The standard dextran with known molecular weight was used as the molecular weight reference substance of polysaccharide.

Analysis of RF-1 structure by GC-MS. Samples of polysaccharides were weighed at $25 \mathrm{mg}$, and $2 \mathrm{ml}$ anhydrous dimethyl sulfoxide was added to fully dissolve them. Subsequently, $400 \mathrm{mg}$ pre-dried sodium hydroxide powder was added, dissolved under ultrasound for $10 \mathrm{~min}$ and stirred for $1 \mathrm{~h}$ at room temperature. Finally, $1.5 \mathrm{ml}$ iodomethane was added, and $5 \mathrm{ml}$ distilled water was added to terminate the reaction. The product was extracted with chloroform. The methylated polysaccharides were hydrolyzed using trifluoroacetic acid and washed 3 times to obtain the products of complete acid hydrolysis of methylated polysaccharides (17). A total of $2 \mathrm{ml}$ anhydrous pyridine, $2 \mathrm{ml}$ hexamethyl-disilazane and $1 \mathrm{ml}$ chlorotrimethylsilane were in turn added to the aforementioned samples. The reaction time was $20 \mathrm{~min}$ at $50^{\circ} \mathrm{C}$. After centrifugation at $16,670 \mathrm{x} \mathrm{g}$ for $20 \mathrm{~min}$ at $4^{\circ} \mathrm{C}$., the upper solution was used for GC-MS analysis as previously described (18).

NMR analysis. Polysaccharide samples of $10 \mathrm{mg}$ (for ${ }^{1} \mathrm{H}$ NMR) and $50 \mathrm{mg}$ (for ${ }^{13} \mathrm{C}$ NMR) were collected. After dissolving the samples with $0.5 \mathrm{ml}$ deuterium oxide, the spectra of ${ }^{1} \mathrm{H}$ NMR, ${ }^{13} \mathrm{C}$ NMR, ${ }^{1} \mathrm{H}-{ }^{1} \mathrm{H}$ correlated spectrometry $\left({ }^{1} \mathrm{H}-{ }^{-1} \mathrm{H}\right.$ COSY), heteronuclear multiple quantum correlation (HMQC) and heteronuclear multiple bond correlation (HMBC) were measured using an NMR spectrometer. Tetramethylsilane was used as an internal standard (19). The novelty of polysaccharide structure was analyzed by searching on the SciFinder database (20).

Antitumor activity of RF-1 in vivo. The mouse sarcoma S180 cell line was purchased from The Cell Bank of Type Culture Collection of the Chinese Academy of Sciences. S180 cells were cultured in RPMI-1640 medium (Thermo Fisher Scientific, Inc.) supplemented with $10 \%$ inactivated FBS (Invitrogen; Thermo Fisher Scientific, Inc.), $100 \mu \mathrm{g} / \mathrm{ml}$ penicillin and $100 \mu \mathrm{g} / \mathrm{ml}$ streptomycin at $37^{\circ} \mathrm{C}$ with $5 \% \mathrm{CO}_{2}$ 
A

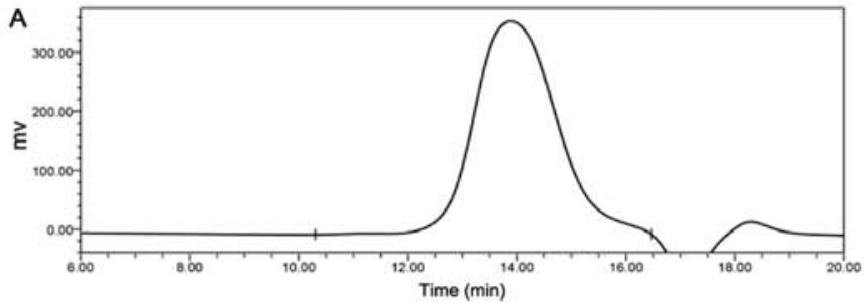

B

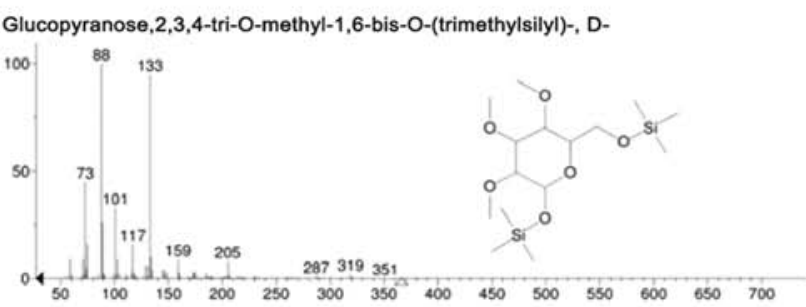

B-D-Glucopyranoside,methyl 2,3,6-tri-O-methyl-4-O-(trimethylsilyl)-

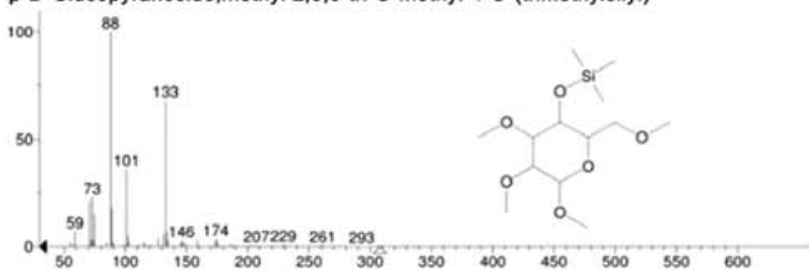

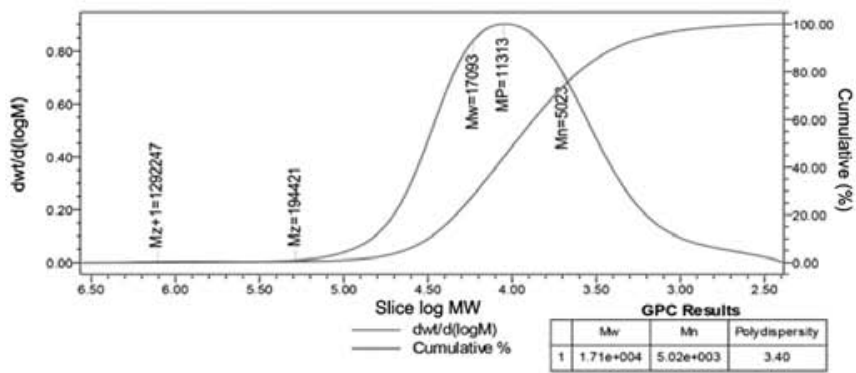

Glucopyranose,2,3,di-O-methyl-1,4,6-tris-O-(trimethyl)-

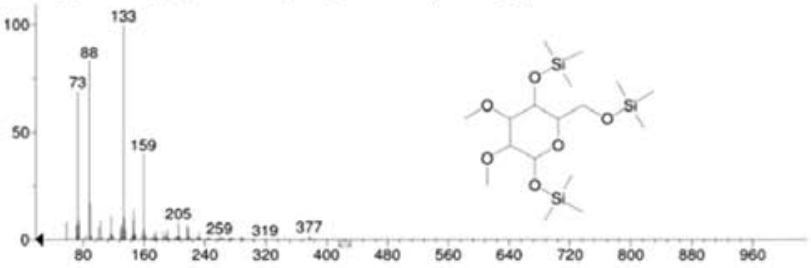

Galactopyranose,3,4-di-0-methyl-1,2,6-tris-0-(trimethylsilyl)-

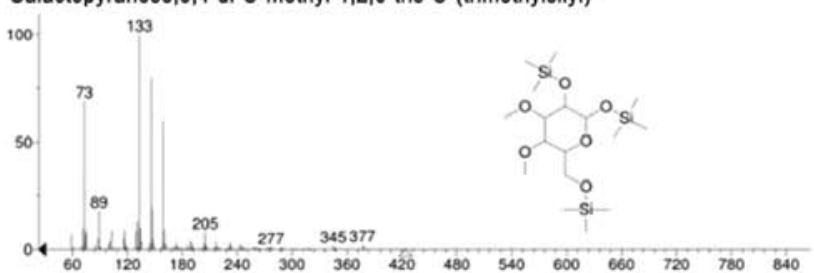

Figure 1. (A) Molecular weight determination spectrum of RF-1 by high-performance gel permeation chromatography. (B) Gas chromatography-mass spectrometry analysis of RF-1. RF-1, Ramaria flaccida (Fr.) Quél. polysaccharide; Mw, average molecular weight; Mn, number average Mw; MP, peak $\mathrm{Mw} ; \mathrm{Mz}, \mathrm{Z}$ average Mw; Mz+1, Z+1 average Mw.

and were sub-cultured every 2 days. Kunming strain female mice obtained from the Institute of Biochemistry and Molecular Immunology of North Sichuan Medical College (Nanchong, China) were inoculated with $100 \mu 1 \mathrm{~S} 180$ tumor cells at a concentration of $3 \times 10^{6} \mathrm{CFU} / \mathrm{ml}$ under the left axillary skin. The Kunming strain mice (age, 4-6 weeks) weighed $25.0 \pm 1.0 \mathrm{~g}$ and were divided into three groups, with 5 mice in each group, and 5 mice were housed per plastic cage with wood chip bedding in an animal room with a 12-h light and 12-h dark cycle at room temperature $\left(25 \pm 2^{\circ} \mathrm{C}\right)$, with free access to standard laboratory diet. After 7 days, each mouse was treated with $20 \mathrm{mg} / \mathrm{kg} \mathrm{RF}-1$ (RF-1 group) or $20 \mathrm{mg} / \mathrm{kg}$ mannatide (positive control group) for 7 consecutive days (21). The mice were sacrificed under anesthesia using $100 \mathrm{mg} / \mathrm{kg}$ ketamine and $15 \mathrm{mg} / \mathrm{kg}$ xylazine. The respiration, cardiac function, corneal reflex, muscle tone and mucous membrane color were checked to verify the death of the mice in the present study. The following formula was used to calculate tumor volume: $\mathrm{V}=\left(\right.$ length $\mathrm{x}$ width $\left.{ }^{2}\right) / 2(22)$. The tumor inhibition rate was calculated as follows: Tumor inhibition rate $(\%)=[(\mathrm{A}-\mathrm{B}) / \mathrm{A}]$ $\mathrm{x} 100$, with $\mathrm{A}$ and $\mathrm{B}$ being the average tumor weight of the blank control group and treated group, respectively (21). The animal experiments were conducted according to the Guidelines for Animal Experimentation of the North Sichuan Medical College of China, which were revised according to the Regulations on the Administration of Experimental Animals of the People's Republic of China (decree no. The Second Commission of the People's Republic of China of Science and Technology Commission). The experimental protocols were approved by the North Sichuan Medical College of China.
RNA extraction, library preparation and sequencing. Total RNA of tumor tissues was extracted using the TRIzol ${ }^{\circledR}$ reagent kit (Invitrogen, Thermo Fisher Scientific, Inc.), according to the manufacturer's protocol. After the samples were quantified, the library was constructed and checked, and subsequently sequenced using an Illumina Hiseq platform $(23,24)$. Genes with an adjusted $\mathrm{P}<0.05$ identified by DESeq2 $(25,26)$ were classified as differentially expressed. Subsequently, the clusterProfiler R package (27) was used for Gene Ontology (GO) analysis and Kyoto Encyclopedia of Genes and Genomes (KEGG) pathways analysis $(27,28)$. Differentially expressed genes were analyzed using the edgeR program (version 3.11) (29).

Effect of RF-1 on the expression levels of $I L-1 \beta, I L-6$, $T N F \alpha, V E G F R$ and VEGF in mice tumor tissues. Tumor tissues were cut and collected into $1.5 \mathrm{ml}$ Eppendorf tubes. After adding $300 \mu 1$ cell lysis solution (Thermo Fisher Scientific, Inc.) containing phosphatase inhibitors (Thermo Fisher Scientific, Inc.) and phenylmethylsulfonyl fluoride to each tube, tissues were ground on ice and beaten into homogenates at $0^{\circ} \mathrm{C}$ for $30 \mathrm{~min}$. After centrifugation at $16,670 \mathrm{x} \mathrm{g}$ at $4^{\circ} \mathrm{C}$ for $20 \mathrm{~min}$, the supernatant was collected into new tubes. The samples were tested using the IL-1 $\beta$ (cat. no. MAB401), IL-6 (cat. no. DY206), TNFa (cat. no. MAB6902), VEGFR (cat. no. DVR100C) and VEGF (cat. no. 493-MV) ELISA kits.

Statistical analysis. All data are presented as the mean \pm SD $(\mathrm{n}=5)$, and SPSS v17 software (SPSS, Inc.) was used to analyze 
Table I. Gas chromatography-mass spectrometry results of methylation analysis of the Ramariaflaccida (Fr.) Quél. polysaccharide.

\begin{tabular}{lcr}
\hline Methylated sugar & Linkage & $\mathrm{m} / \mathrm{z}$ \\
\hline $2,3,4-\mathrm{Me}-1,6-G l c$ & $1,6-$ & 597388101117133159185205229265287319351 \\
$2,3-\mathrm{Me}-1,4,6-G l c$ & $1,4,6-$ & 7388103133146159191205217247259319361377435 \\
$2,3,6-\mathrm{Me}-4-\mathrm{Glc}$ & $4-$ & 597388101133146174207229261293 \\
$3,4-\mathrm{Me}-1,2,6-\mathrm{Gal}$ & $1,2,6-$ & 7389103133146159205232277317345377
\end{tabular}

the differences between the blank control group and the experimental groups using one-way ANOVA followed by Dunnett's test. $\mathrm{P}<0.05$ was considered to indicate a statistically significant difference.

\section{Results}

Molecular weight analysis of $R F-1$. As shown in Fig. 1A, the HPGPC elution curve of RF-1 displayed a symmetrical peak, and the average molecular weight (Mw) of RF-1 was 17,093 Da, the number-average Mw (Mn) was 5,023 Da, the peak Mw (Mp) was $11,313 \mathrm{Da}$, the $\mathrm{Z}$ average $\mathrm{Mw}(\mathrm{Mz})$ was 194,421 Da, the Z+1 average Mw (Mz+1) was 129,247 Da and the polydispersity index $(\mathrm{D}=\mathrm{Mw} / \mathrm{Mn})$ was $3.40 \mathrm{Da}$. Therefore, the present data indicated that RF-1 is a homogeneous polysaccharide.

Analysis of the GC-MS experiment results. The GC-MS results of RF-1 (Table I and Fig. 1B) indicated that the glucopyranose residues were mainly 2,3,4-Me-1,6-substituted, 2,3-Me-1,4,6-substituted and 2,3,6-Me-4-substituted. The glucopyranose residues have 1,6- and 1,4,6-bonding modes and 4-terminal forms. The galactopyranose residues are mainly 3,4-Me-1,2,6-substituted, indicating that galactopyranose residues are 1,2,6-linked. According to the peak area of each monosaccharide in GC-MS, it can be calculated that 1,6-Glu: 1,4,6-Glu: 4-Glu: 1,2,6-Gal=1:1:3:2.

Analysis of the NMR experiment results. In ${ }^{1} \mathrm{H}$ NMR (400 MHz), the chemical shifts of most protons on C2-C6 were in the range of $\delta 3.15-\delta 4.19$, due to the shielding effect of hydroxyl groups. The anomeric protons of polysaccharide fell in the region of $84.3-5.0 \mathrm{ppm}$. As shown in Fig. 2A, RF-1 displayed six heterologous hydrogen signals $(\delta 4.99, \delta 4.95$, $\delta 4.90, \delta 4.88, \delta 4.42$ and $\delta 4.39)$. Among them, $84.99, \delta 4.95$, $\delta 4.90$ and $\delta 4.88$ were signals of the $\alpha$-pyranose unit, while the signals of $\delta 4.42$ and $\delta 4.39$ were in the form of $\beta$-pyranose.

In the 95-105 ppm region of the ${ }^{13} \mathrm{CNMR}(400 \mathrm{MHz})$ of RF-1, the signal peaks of $C_{1}$ were $\delta 103.01, \delta 102.92, \delta 102.44, \delta 101.35$, $\delta 97.95$ and $\delta 97.89$ (Fig. 2B). The anomeric carbons in RF-1 displayed $\alpha$ and $\beta$ heterochromatic configurations. Resonance in the $\delta 101-104 \mathrm{ppm}$ region was attributed to the anomeric carbon atoms of D-glucopyranose. The $\delta 96-101$ ppm region was the anomeric carbon atom signal of D-galactopyranose. In the range of $\delta 170-180 \mathrm{ppm}$, there was no carboxyl resonance signal of alduronic acid, which indicated that RF-1 is a neutral polysaccharide. There was no resonance signal of a furan ring at $\delta 106-109$ ppm, suggesting that all monosaccharide residues were in the pyranoid configuration.
${ }^{1} \mathrm{H}-{ }^{1} \mathrm{H}$ COSY is a kind of homonuclear chemical shift correlation spectrum. It refers to the coupling correlation spectrum among protons in the same coupling system. It is mainly used to study the ${ }^{1} \mathrm{H}$ homonuclear coupling system (30). In the ${ }^{1} \mathrm{H}-{ }^{1} \mathrm{H}$ COSY spectrum of RF-1, there were cross peaks at $\delta 4.99 / \delta 3.78, \delta 4.95 / \delta 3.71, \delta 4.90 / \delta 3.75, \delta 4.88 / \delta 3.71, \delta 4.42 / \delta 3.24$ and $\delta 4.39 / \delta 3.22$ (Fig. 2C). The results of the present study indicated that the $\mathrm{H} 2$ shifts of RF-1 were 3.78, 3.71, 3.75, 3.71, 3.24 and $3.22 \mathrm{ppm}$. According to the chemical shifts of $\mathrm{H} 2$, the chemical shifts of $\mathrm{H} 3$ can be identified to further detect the chemical shifts of H4-H6. Based on the aforementioned results, the hydrogen signals of monosaccharides in RF-1 in the ${ }^{1} \mathrm{H}$ NMR spectra were assigned and listed in Table II.

HMQC reflects the coupling association between directly connected ${ }^{1} \mathrm{H}$ and ${ }^{13} \mathrm{C}$ nuclei $(31,32)$. After assigning the chemical shifts of the hydrogen nuclei in RF-1 via the ${ }^{1} \mathrm{H}-{ }^{1} \mathrm{H}$ COSY spectrum, the chemical shifts of the carbon nuclei can be assigned via the HMQC spectra. In the HMQC spectrum of RF-1 (Fig. 2D), there were cross peaks at H1/C1 (4.99/102.44), H1/C1 (4.95/101.35), H1/C1 (4.90/97.95), H1/C1 (4.88/97.89), $\mathrm{H} 1 / \mathrm{C} 1$ (4.42/102.92) and $\mathrm{H} 1 / \mathrm{C} 1$ (4.39/103.01). Therefore, the chemical shifts of C1-C6 were identified in the HMQC spectrum (Table II).

HMBC reflects information associated with carbon and hydrogen remotely. By associating ${ }^{1} \mathrm{H}$ with long-range coupled ${ }^{13} \mathrm{C}$ nuclei, structural information of the molecular skeleton can be provided. According to the HMBC spectrum of RF-1 (Fig. 2E) and the chemical shift attribution table of hydrogen and carbon (Table II), it was identified that A-C6 and B-H4, A-H1 and F-C4, C-H1 and D-C6, C-C6 and D-H1, and C-H2 and $\mathrm{E}-\mathrm{C} 4$ had correlative coupling associations. This indicated that $\mathrm{A}$ and $\mathrm{B}$ were connected by $6 \rightarrow 4, \mathrm{~A}$ and $\mathrm{F}$ by $1 \rightarrow 4, \mathrm{C}$ and $\mathrm{D}$ by $1 \rightarrow 6$, and $\mathrm{C}$ and $\mathrm{E}$ by $2 \rightarrow 4$.

Based on the analysis of the aforementioned experimental results, the RF-1 structure wasidentified and shown in Fig.2F. The main chain of RF-1 consisted of $(1 \rightarrow 6,2)$ - $\alpha$-D-galactopyranose and $(1 \rightarrow 6,4)-\alpha$-D-glucopyranose. One of the branched chains was linked to $4-\mathrm{O}$ of the main glucose chain by $(1 \rightarrow 6)-\alpha$-D-glucopyranose and next linked by one $(\rightarrow 4)-\beta$-D-glucopyranose. The other two branched chains were both linked to $2-\mathrm{O}$ of the main glucose chain by one $(\rightarrow 4)-\beta$-D-glucopyranose. The structure of the polysaccharide resulted novel by searching the SciFinder database.

Antitumor activity of RF-1 in vivo. The inhibitory effect of a treatment on tumors is usually judged by the tumor size and the inhibitory rate of the treatment on the tumor. S180 cells are commonly used as cell lines to detect the antineoplastic activity of treatment in vivo (32). The results from the in vivo 
A

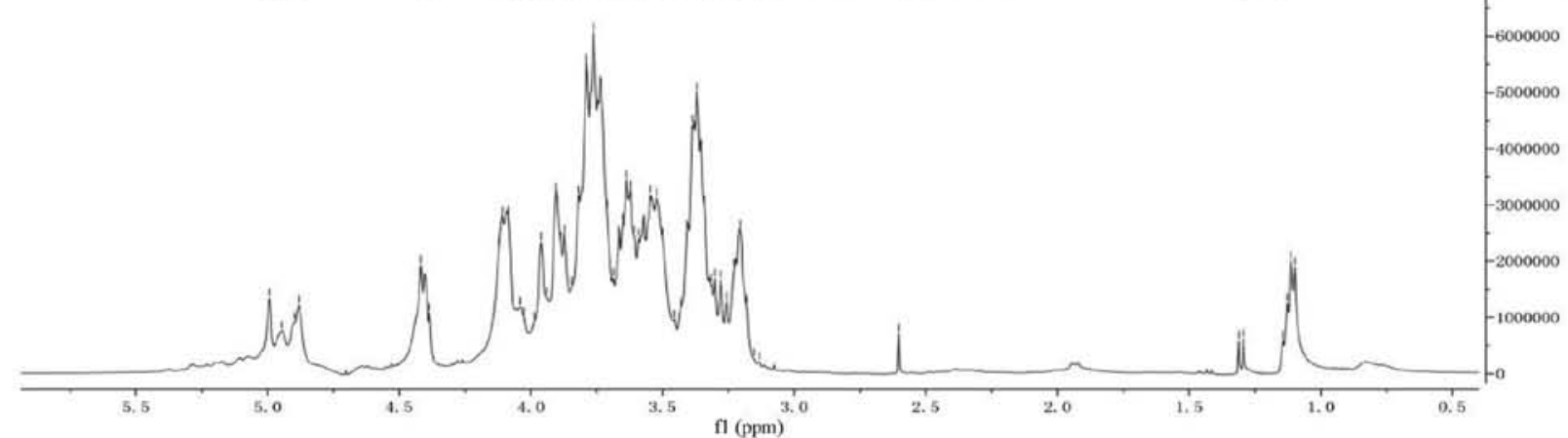

B

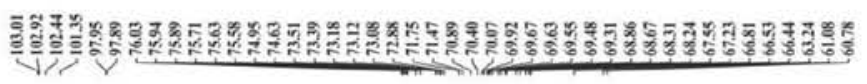
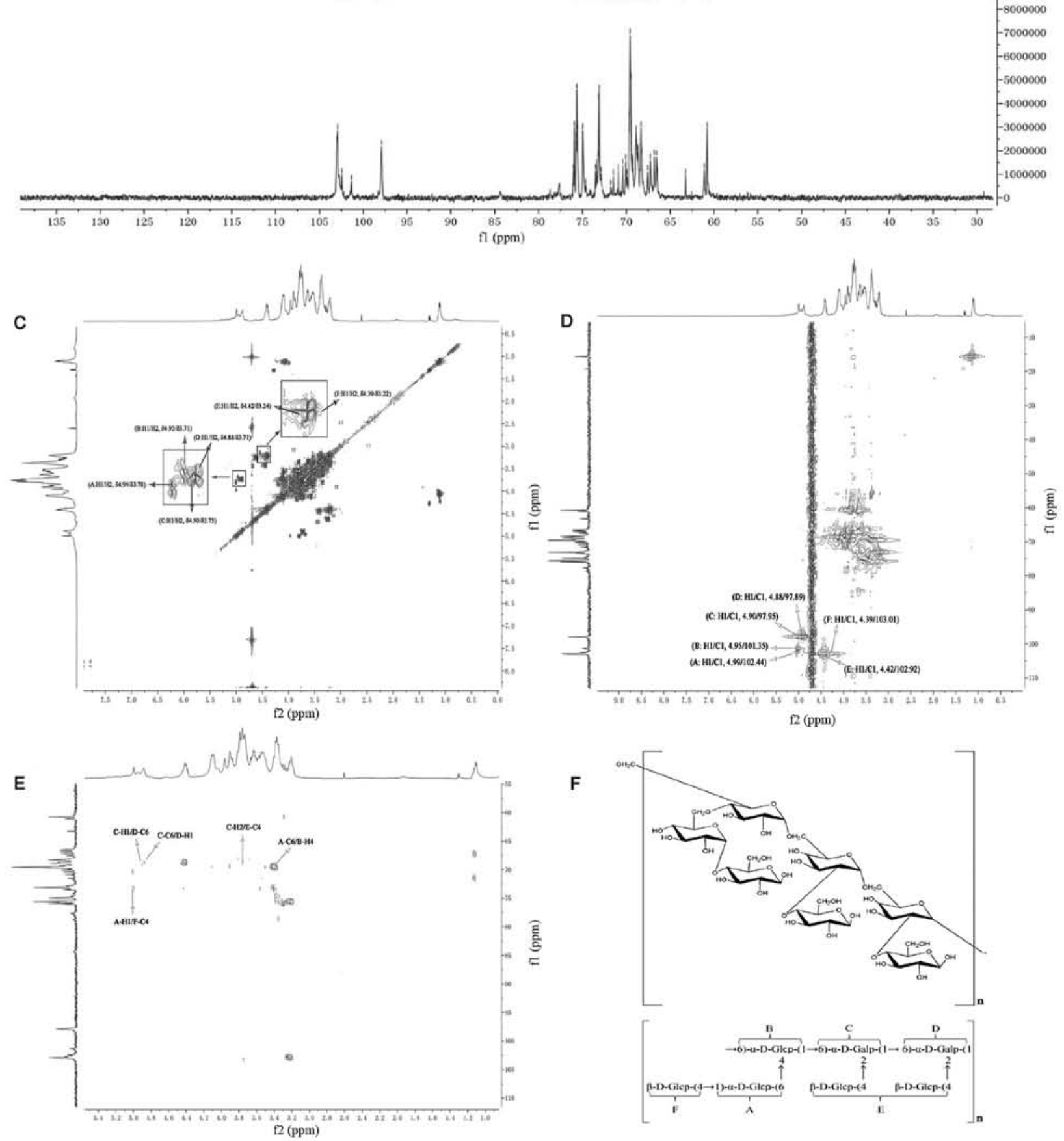

Figure 2. (A) The ${ }^{1} \mathrm{H}$ NMR spectra of RF-1. (B) The ${ }^{13} \mathrm{C}$ NMR spectra of RF-1. (C) ${ }^{1} \mathrm{H}-{ }^{-1} \mathrm{H}$ correlated spectrometry spectrum of RF-1. (D) Heteronuclear multiple quantum correlation spectrum of RF-1. (E) Heteronuclear multiple bond correlation spectrum of RF-1. (F) Chemical structure of polysaccharide RF-1. RF-1, Ramaria flaccida (Fr.) Quél. polysaccharide; NMR, nuclear magnetic resonance. 
Table II. ${ }^{1} \mathrm{H}$ NMR and ${ }^{13} \mathrm{C}$ NMR chemical shifts in the Ramaria flaccida (Fr.) Quél. polysaccharide.

Chemical shifts, $\delta$, ppm

\begin{tabular}{|c|c|c|c|c|c|c|}
\hline Residue & $\mathrm{H} 1 / \mathrm{C} 1$ & $\mathrm{H} 2 / \mathrm{C} 2$ & $\mathrm{H} 3 / \mathrm{C} 3$ & $\mathrm{H} 4 / \mathrm{C} 4$ & $\mathrm{H} 5 / \mathrm{C} 5$ & H6/C6 \\
\hline$A \rightarrow 6)-\alpha-D-G l c p-(1 \rightarrow$ & $4.99 / 102.44$ & $3.78 / 60.40$ & $3.56 / 73.09$ & $3.40 / 69.45$ & $3.80 / 68.34$ & $3.56 / 69.48$ \\
\hline $\mathrm{B} \rightarrow 4,6)-\alpha-\mathrm{D}-\mathrm{Glcp}-(1 \rightarrow$ & $4.95 / 101.35$ & $3.71 / 66.05$ & $3.47 / 69.92$ & $3.39 / 60.88$ & $3.32 / 66.23$ & $3.19 / 69.42$ \\
\hline $\mathrm{C} \rightarrow 2,6)-\alpha-\mathrm{D}-\mathrm{Galp}-(1 \rightarrow$ & $4.90 / 97.95$ & $3.75 / 71.47$ & $3.41 / 69.20$ & $3.64 / 67.23$ & $3.52 / 74.63$ & $3.75 / 68.65$ \\
\hline $\mathrm{D} \rightarrow 2,6)-\alpha-\mathrm{D}-$ Galp- $(1 \rightarrow$ & $4.88 / 97.89$ & $3.71 / 71.76$ & $3.50 / 66.43$ & $3.39 / 74.37$ & $3.68 / 68.32$ & $4.09 / 69.26$ \\
\hline E- $\beta$-D-Glcp- $(4 \rightarrow$ & $4.42 / 102.92$ & $3.24 / 69.51$ & $3.42 / 69.45$ & $3.85 / 68.34$ & $3.56 / 71.95$ & $4.08 / 67.06$ \\
\hline F- $\beta$-D-Glcp- $(4 \rightarrow$ & $4.39 / 103.01$ & $3.22 / 75.70$ & $3.51 / 72.83$ & $3.67 / 73.34$ & $3.34 / 75.78$ & $3.25 / 73.08$ \\
\hline
\end{tabular}

NMR, nuclear magnetic resonance.
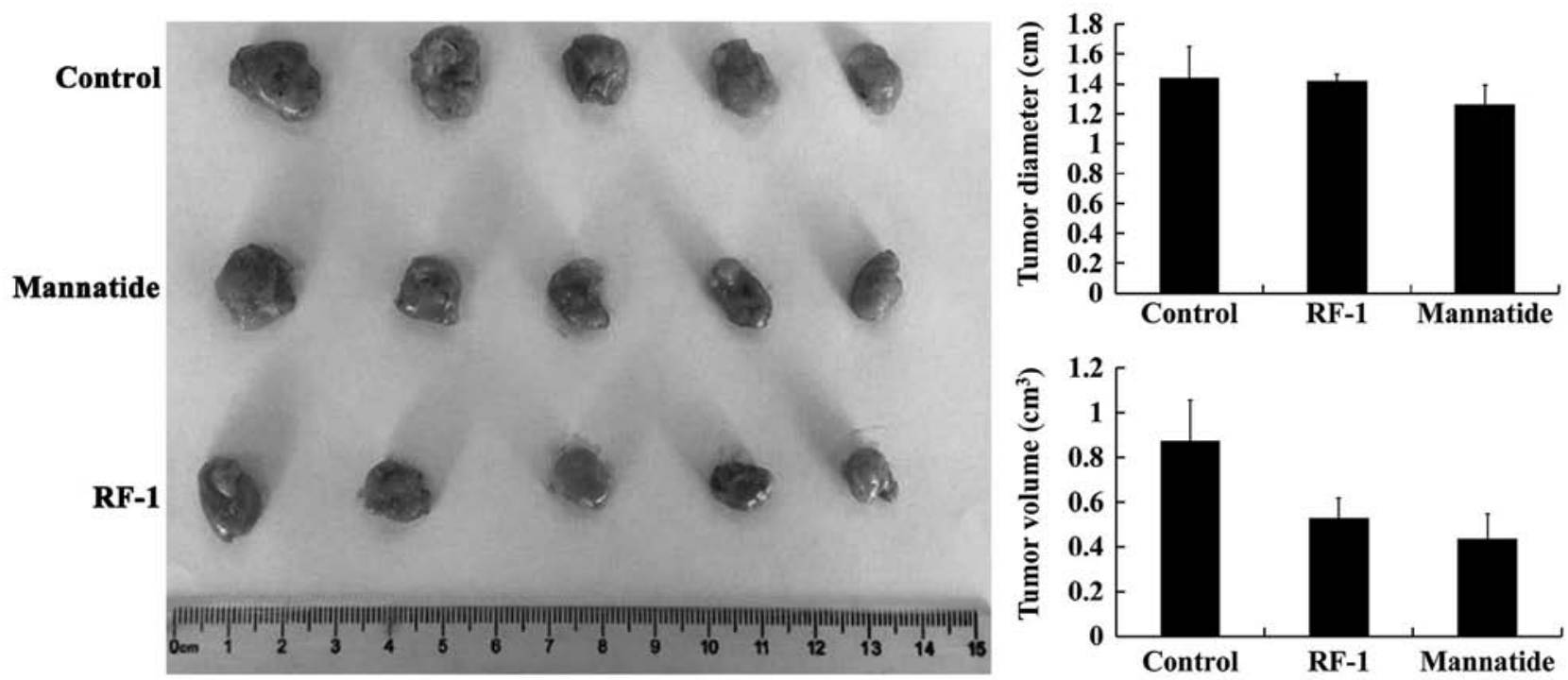

Figure 3. Antitumor activity of RF-1 in vivo. Model, blank control group; RF-1, RF-1 group treated with $20 \mathrm{mg} / \mathrm{kg}$ RF-1; Mannatide, positive control group treated with $20 \mathrm{mg} / \mathrm{kg}$ mannatide; RF-1, Ramaria flaccida (Fr.) Quél. polysaccharide.

experiments are shown in Fig. 3 and Table III. The maximum tumor volume observed in the blank control, RF-1 and mannatide groups was $1.054,0.618$ and $0.545 \mathrm{~cm}^{3}$, respectively. The maximum diameter observed in the blank control, RF-1 and mannatide groups was $1.687,1.482$ and $1.398 \mathrm{~cm}$, respectively. Additionally, there was almost no difference in the average liver weight, the average spleen weight and the average thymus weight between the two groups, which indicated that RF-1 did not damage the liver, spleen and thymus (Table III). The inhibition rate of the treatments in the mouse S180 tumors was $40.00 \%$ in the RF-1 group and $53.81 \%$ in the mannatide group. The average weight of the tumors in the RF-1 group was $0.58 \pm 0.1 \mathrm{~g}$, which was lower than that in the blank control group $(0.96 \pm 0.20 \mathrm{~g})$, and the average weight of the tumors in the mannatide group was $0.48 \pm 0.12 \mathrm{~g}$ (Table III). The present results suggest that RF-1 may have a strong antitumor effect in vivo.

Transcriptome sequencing data. Illumina sequencing technology was used to sequence the transcriptomes of tumor tissues in the blank control and RF-1 groups. After original data filtering, sequence error rate checking and detection of GC content distribution, the clean reads for subsequent analysis were 599,771,500 and 59,981,170 bp in length, respectively (data not shown). After quality control, two groups of clean reads were compared with the reference genome, and the percentage of total annotated genes was 94.51 and $94.3 \%$, respectively, which provides a good basis for the follow-up analysis (data not shown).

Quantitative analysis of gene expression. The sequencing results revealed that in the blank control group, 12,203 genes were expressed [fragments per kilobase million (FPKM) $\geq 1$ ], accounting for $23.18 \%$ of the total number of genes, and 1,052 genes were upregulated (FPKM>60), accounting for $2.00 \%$ of the total number of genes. In the RF-1 group, 12,155 genes were expressed, accounting for $23.09 \%$ of the total number of genes, and 1,044 genes were upregulated, accounting for $1.98 \%$ of the total number of genes. Additionally, there were upregulated genes with different FPKM in the blank control and RF-1 groups. The results revealed that 13 genes [cytochrome c oxidase subunit 1 (mt-Col), ribosomal protein 
Table III. Antitumor activities of RF-1 on S180 tumor in vivo.

\begin{tabular}{lcccccccc}
\hline & $\begin{array}{c}\text { Average } \\
\text { liver } \\
\text { weight, g }\end{array}$ & $\begin{array}{c}\text { Average } \\
\text { spleen } \\
\text { weight, g }\end{array}$ & $\begin{array}{c}\text { Average } \\
\text { thymus } \\
\text { weight, g }\end{array}$ & $\begin{array}{c}\text { Average } \\
\text { mouse } \\
\text { weight, g }\end{array}$ & $\begin{array}{c}\text { Average } \\
\text { tumor } \\
\text { diameter, cm }\end{array}$ & $\begin{array}{c}\text { Average } \\
\text { tumor } \\
\text { volume, } \mathrm{cm}^{3}\end{array}$ & $\begin{array}{c}\text { Average } \\
\text { tumor } \\
\text { weight, g }\end{array}$ & $\begin{array}{c}\text { Tumor } \\
\text { inhibition } \\
\text { rate, } \%\end{array}$ \\
\hline Control & $1.99 \pm 0.25$ & $0.20 \pm 0.02$ & $0.15 \pm 0.02$ & $29.33 \pm 1.93$ & $1.44 \pm 0.21$ & $0.87 \pm 0.18$ & $0.96 \pm 0.20$ & - \\
RF-1 $(20 \mathrm{mg} / \mathrm{kg})$ & $1.96 \pm 0.20$ & $0.18 \pm 0.02$ & $0.12 \pm 0.01$ & $27.63 \pm 1.90$ & $1.42 \pm 0.04$ & $0.53 \pm 0.09$ & $0.58 \pm 0.1^{\mathrm{a}}$ & 40.00 \\
Mannatide $(20 \mathrm{mg} / \mathrm{kg})$ & $2.25 \pm 0.29$ & $0.26 \pm 0.05$ & $0.19 \pm 0.09$ & $30.70 \pm 2.75$ & $1.26 \pm 0.13$ & $0.44 \pm 0.11$ & $0.48 \pm 0.12^{\mathrm{b}}$ & 53.81 \\
\hline
\end{tabular}

${ }^{\mathrm{a}} \mathrm{P}<0.05$; ${ }^{\mathrm{b}} \mathrm{P}<0.01$ vs. control group. RF-1, Ramaria flaccida (Fr.) Quél. polysaccharide.

Table IV. Quantification of gene expression in the blank control group (FPKM $>2,000)$.

\begin{tabular}{|c|c|c|c|c|c|}
\hline Gene ID & FPKM & Gene name & Gene length, bp & Gene biotype & Gene description \\
\hline ENSMUSG00000064351 & 5108.05 & mt-Co1 & 1545 & Protein coding & $\begin{array}{l}\text { Mitochondrially encoded } \\
\text { cytochrome c oxidase I }\end{array}$ \\
\hline ENSMUSG00000007892 & 4231.249 & Rplp1 & 499 & Protein coding & Ribosomal protein, large, $\mathrm{P} 1$ \\
\hline ENSMUSG00000037742 & 3449.332 & Eef1a1 & 2493 & Protein coding & $\begin{array}{l}\text { Eukaryotic translation } \\
\text { elongation factor } 1 \alpha 1\end{array}$ \\
\hline ENSMUSG00000057863 & 3290.97 & Rpl36 & 404 & Protein coding & Ribosomal protein L36 \\
\hline ENSMUSG00000068396 & 2824.368 & Rpl34-ps1 & 354 & Processed pseudogene & Ribosomal protein L36 \\
\hline ENSMUSG00000068220 & 2782.246 & Lgals1 & 800 & Protein coding & $\begin{array}{l}\text { Lectin, galactose binding, } \\
\text { soluble } 1\end{array}$ \\
\hline ENSMUSG00000064370 & 2689.116 & mt-Cytb & 1144 & Protein coding & $\begin{array}{l}\text { Mitochondrially encoded } \\
\text { cytochrome b }\end{array}$ \\
\hline ENSMUSG00000083061 & 2613.918 & Gm12191 & 348 & Processed pseudogene & Predicted gene 12191 \\
\hline ENSMUSG00000064341 & 2495.384 & mt-Nd1 & 957 & Protein coding & $\begin{array}{l}\text { Mitochondrially encoded } \\
\text { NADH dehydrogenase } 1\end{array}$ \\
\hline ENSMUSG00000083773 & 2243.619 & Gm13394 & 1000 & Processed pseudogene & Predicted gene 13394 \\
\hline ENSMUSG00000000740 & 2200.529 & Rpl13 & 2595 & Protein coding & ribosomal protein L13 \\
\hline ENSMUSG00000003970 & 2166.688 & Rpl8 & 862 & Protein coding & ribosomal protein L8 \\
\hline ENSMUSG00000091957 & 2162.028 & Rps2-ps 10 & 965 & $\begin{array}{l}\text { Transcribed processed } \\
\text { pseudogene }\end{array}$ & $\begin{array}{l}\text { ribosomal protein } S 2 \text {, } \\
\text { pseudogene } 10\end{array}$ \\
\hline
\end{tabular}

FPKM, fragments per kilobase million.

lateral stalk subunit P1 (Rplp1), eukaryotic translation elongation factor $1 \alpha 1$ (Eef1a1), ribosomal protein L36 (Rpl36), ribosomal protein L34-pseudogene 1 (Rpl34-ps1), galectin 1 (Lgals1), mitochondrion Cytochrome b (mt-Cytb), predicted gene 12191 (Gm12191), NADH-ubiquinone oxidoreductase chain 1 (mt-Nd1), Gm13394, Rpl13, Rpl8 and Rps2-ps10] were markedly upregulated (FPKM $>2,000)$ in the blank control group compared with in the RF-1 group (Table IV), and 13 genes (mt-Co1, Rplp1, Eef1a1, mt-Nd1, Lgals1, Rpl36, mt-Cytb, Gm13394, Gm12191, Rpl34-ps1, Rpl8, Rpl13 and Rps2-ps10) were markedly upregulated (FPKM>2,000) in the RF-1 group compared with in the blank control group (Table V). Notably, the FPKM of the Rplp1 gene was 4,231.249 in the blank control group and 3,969.035 in the RF-1 group, the FPKM of the Rpl36 gene was 3,290.970 in the blank control group and 2,590.419 in the RF-1 group, and the FPKM of the Rpl34 gene was 2,824.368 in the blank control group and 2,261.856 in the RF-1 group. The present results indicated that Rplp1 was a key gene. RPLP1 interacts with the conservative regions of RPLP0, RPLP2 and $28 \mathrm{~S}$ rRNA, which forms the main part of the ribosomal GTPase activity center, and can covalently bind to ubiquitin to form fusion proteins and participate in important biological activities (32), which was consistent with regulating cell apoptosis and transcription in the RF-1 group of the present study. The Rpl36 gene is directly involved in the synthesis of the ribosomal protein $50 \mathrm{~S}$ subunit, while the Rpl34 gene belongs to the ribosomal protein L34E family, and is considered to serve an important role in apoptosis, and in the occurrence and development of various malignant tumors $(33,34)$. Previous studies demonstrated that the expression levels of Rpl34 and Rpl36 gene were downregulated in the RF-1 group, indicating that cell mitosis was significantly slowed down, cell proliferation was significantly inhibited, and cell apoptosis 
Table V. Quantification of gene expression in the Ramaria flaccida (Fr.) Quél. polysaccharide group (FPKM >2,000).

\begin{tabular}{|c|c|c|c|c|c|}
\hline Gene ID & FPKM & Gene name & Gene length, bp & Gene biotype & Gene description \\
\hline ENSMUSG00000064351 & 6474.749 & mt-Co1 & 1545 & Protein coding & $\begin{array}{l}\text { Mitochondrially encoded } \\
\text { cytochrome c oxidase I }\end{array}$ \\
\hline ENSMUSG00000007892 & 3969.035 & Rplp1 & 499 & Protein coding & Ribosomal protein, large, $\mathrm{P} 1$ \\
\hline ENSMUSG00000037742 & 3079.388 & Eef1a1 & 2493 & Protein coding & $\begin{array}{l}\text { Eukaryotic translation } \\
\text { elongation factor } 1 \alpha 1\end{array}$ \\
\hline ENSMUSG00000064341 & 2940.164 & $\mathrm{mt}-\mathrm{Nd} 1$ & 957 & Protein coding & $\begin{array}{l}\text { Mitochondrially encoded } \\
\text { NADH dehydrogenase } 1\end{array}$ \\
\hline ENSMUSG00000068220 & 2762.111 & Lgals1 & 800 & Protein coding & $\begin{array}{l}\text { Lectin, galactose binding, } \\
\text { soluble } 1\end{array}$ \\
\hline ENSMUSG00000057863 & 2590.419 & Rpl36 & 404 & Protein coding & Ribosomal protein L36 \\
\hline ENSMUSG00000064370 & 2471.775 & mt-Cytb & 1144 & Protein coding & $\begin{array}{l}\text { Mitochondrially encoded } \\
\text { cytochrome b }\end{array}$ \\
\hline ENSMUSG00000083773 & 2297.863 & Gm13394 & 1000 & Processed pseudogene & Predicted gene 13394 \\
\hline ENSMUSG00000083061 & 2274.003 & Gm12191 & 348 & Processed pseudogene & Predicted gene 12191 \\
\hline ENSMUSG00000068396 & 2261.856 & Rpl34-ps1 & 354 & Processed pseudogene & $\begin{array}{l}\text { Ribosomal protein L34, } \\
\text { pseudogene } 1\end{array}$ \\
\hline ENSMUSG00000003970 & 2137.731 & Rpl8 & 862 & Protein coding & Ribosomal protein L8 \\
\hline ENSMUSG00000000740 & 2122.002 & Rpl13 & 2595 & Protein coding & Ribosomal protein L13 \\
\hline ENSMUSG00000091957 & 2051.634 & Rps2-ps10 & 965 & $\begin{array}{l}\text { Transcribed processed } \\
\text { pseudogene }\end{array}$ & $\begin{array}{l}\text { Ribosomal protein } \mathrm{S} 2 \text {, } \\
\text { pseudogene } 10\end{array}$ \\
\hline
\end{tabular}

FPKM, fragments per kilobase million.

was promoted, and that these genes could markedly affect physiological activities in tumor cells $(34,35)$. Although the expression levels of these genes were upregulated in the RF-1 group in the present study, these were lower than those in the blank control group, suggesting that RF-1 may influence the function of some ribosomal subunits in cancer cells, which is consistent with the inhibitory effect of RF-1 on cancer cells in vivo.

Differentially expressed genes between the control and RF-1 groups. By using the edge R program and using $\mathrm{P}<0.05$ and $\mid \log _{2}$ fold-changel $>2$ as the screening criteria (29), 1,971 differentially expressed genes were obtained comparing the blank control group with the RF-1 group. Among these, 818 genes were upregulated, whereas 1,153 genes were downregulated (Fig. 4A). Compared with the blank control group, the top 13 upregulated genes ( $\log _{2}$ fold-changel $>5$ ) in the RF-1 group included endothelin 2, mucin 15, transcription factor AP-2 $\beta$, toll-like receptor 12, BAI1 associated protein $3, \alpha$ tocopherol transfer protein, claudin 8, TIMP metallopeptidase inhibitor 4 , fucosyltransferase 7 , hypocretin receptor 1 , solute carrier family 28 member 3 (Slc28a3), WNT inhibitory factor 1 (Wif1) and CXXC finger protein 4 (Cxxc4) (Table VI), while the top 15 downregulated genes ( $\log _{2}$ fold changel>6.9) included myosin heavy chain 7 (Myh7), myosin light chain 2 (Myl2), Myh2, Myl3, immunoglobulin heavy variable 3-6 (Ighv3-6), calcium voltage-gated channel auxiliary subunit $\gamma$ 6 (Cacng6), Slc8a3, immunoglobulin like domain containing receptor 2 , leucine rich repeats and transmembrane domains 1, Ighv1-76, $\gamma$-aminobutyric acid type A receptor subunit $\alpha 3$,
Ighv2-9, Ighv1-72, phospholipase A2 group IVE (Pla2g4e) and immunoglobulin $\kappa$ chain variable 8-24 (Table VII).

Wif1, which serves an antagonistic role in the WNT signaling pathway (36), was significantly upregulated in the RF-1 group compared with the blank control group. By binding to the WNT ligand, the ligand cannot bind to the cell surface receptor (37), thus inhibiting WNT signal transduction. The Wif1 gene was upregulated in the RF-1 group, suggesting that the WNT signaling pathway was one of the key signal transduction pathways in the RF-1 group. At present, research has mainly focused on the antitumor activity of this gene. Additionally, it has been reported that Wif1 can affect the growth of blood vessels and cells in liver tumors (38). Cxxc4, another factor that serves an antagonistic role in the WNT signaling pathway, was also upregulated, suggesting that it may serve a key role in the inhibition of tumorigenesis and growth. The protein encoded by this gene binds to the PDZ region of disheveled segment polarity protein 1 (Dvl1), which prevents Dvll from forming a complex with Axin (39). The aforementioned results and the analysis of the differentially expressed genes suggest that the antitumor activity of RF-1 in vivo may be associated with the WNT signaling pathway.

GO analysis and KEGG analysis of differentially expressed genes. GO is a comprehensive database describing gene function. An adjusted P-value $($ Padj $)<0.05$ was used as the threshold of significant enrichment for $\mathrm{GO}$ functional enrichment (Fig. 4B). A total of 58,807 genes were associated with GO terms; among them, 47,091 were associated with biological processes, 5,250 with cellular components and 

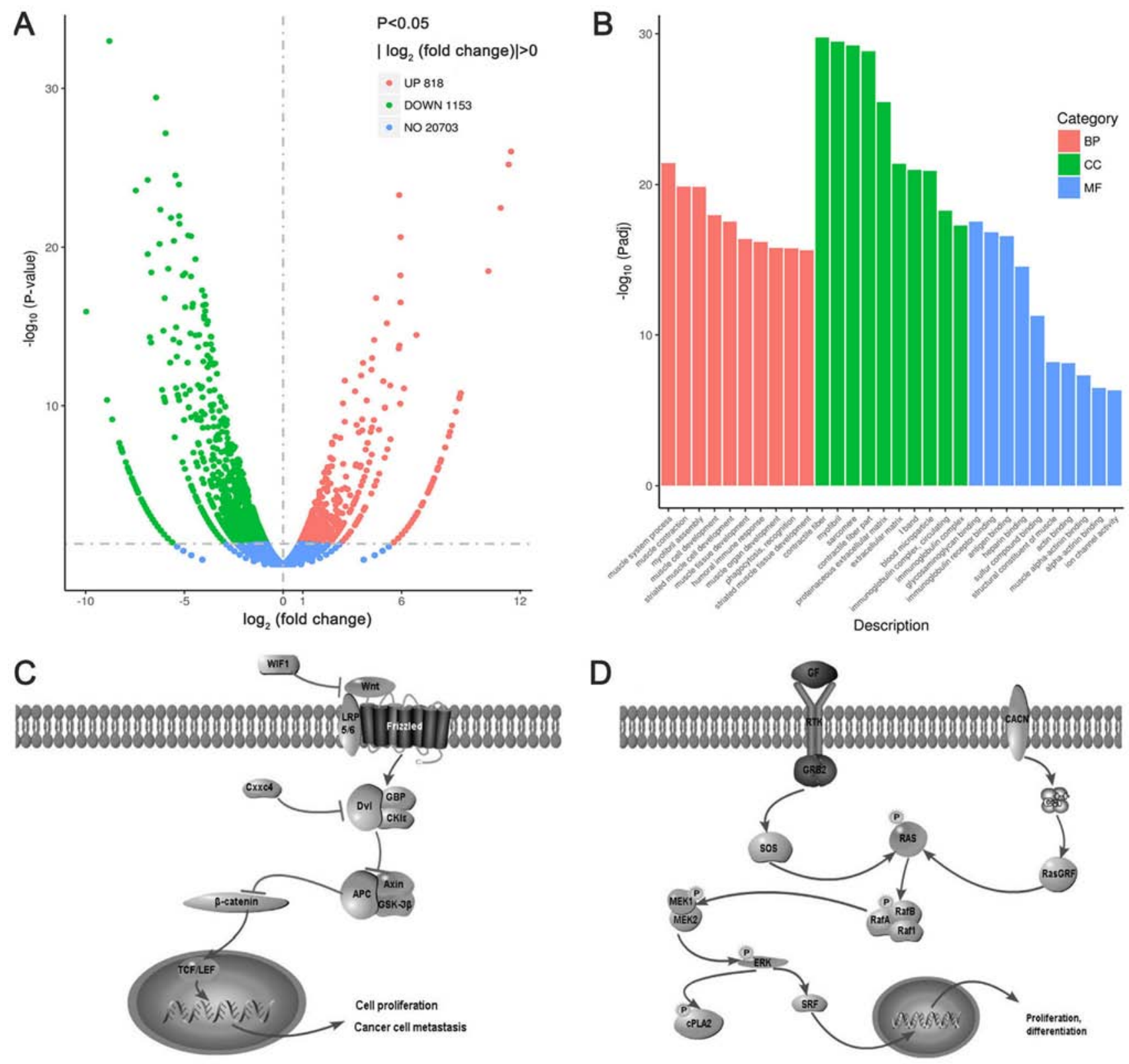

Figure 4. (A) Volcanic plot of differential gene expression analysis between the blank control group and the RF-1 group. (B) Gene Ontology enrichment analysis of the blank control group and the RF-1 group. (C) Schematic diagram of the WNT signaling pathway. (D) Schematic diagram of the MAPK signaling pathway. BP, biological process; CC, cellular component; MF, molecular function; RF-1, Ramaria flaccida (Fr.) Quél. polysaccharide; Padj, adjusted P-value.

6,466 with molecular functions. In the biological processes category, the three terms with the most significant enrichment were 'myofibril assembly' (GO 0030239), 'muscle contraction' (GO 0008038) and 'muscle system process' (GO 0006936). The majority of the terms in the cellular components category were associated with 'contractile fiber' (GO 0043292), 'myofibril' (GO 0030016) and 'sarcomere' (GO 0030017). Under the molecular functions category, the majority of the GO terms were grouped into 'glycosaminoglycan binding' (GO 0005539), 'immunoglobulin receptor binding' (GO 0034987) and 'antigen binding' (GO 0003823). The results indicated that the cytokinetics and immune function of tumor cells in the RF-1 group were different from those in the blank control group.

Padj $<0.05$ was used as the threshold of significant enrichment for KEGG pathway enrichment. The results revealed that the WNT (Fig. 4C) and mitogen-activated protein kinase (MAPK) signaling pathways (Fig. 4D) were significantly enriched, and the number of differentially expressed genes annotated in these two pathways was 19 and 33, respectively (data not shown). The present result supports the hypothesis that the antineoplastic activity of RF-1 in organisms may be achieved through the WNT and MAPK signaling pathways.

The present analysis identified 19 differentially expressed genes in the WNT signaling pathway, 9 of which were upregulated in the RF-1 group, including Wif1, Cxxc4, Wnt family member 7B (Wnt family member 7B), notum palmitoleoyl-protein carboxylesterase, APC regulator of WNT signaling pathway 2 , frizzled class receptor 2 , FRAT regulator of WNT signaling pathway 2 and Wnt6, while 10 were downregulated, including secreted frizzled related protein 5 (Sfrp5), 
Table VI. Differentially expressed (upregulated) genes between the blank control group and the Ramaria flaccida (Fr.) Quél. polysaccharide group (llog 2 fold-changel>5).

\begin{tabular}{|c|c|c|c|c|c|}
\hline Gene ID & $\log _{2}$ fold-change & Gene name & Gene length, bp & Gene biotype & Gene description \\
\hline ENSMUSG00000028635 & 8.997284 & Edn2 & 1462 & Protein coding & Endothelin 2 \\
\hline ENSMUSG00000050808 & 8.752694 & Muc15 & 3569 & Protein coding & Mucin 15 \\
\hline ENSMUSG00000025927 & 8.552894 & Tfap2b & 6338 & Protein coding & Transcription factor AP- $2 \beta$ \\
\hline ENSMUSG00000062545 & 8.208796 & Tlr12 & 3177 & Protein coding & Toll-like receptor 12 \\
\hline ENSMUSG00000047507 & 7.954483 & Baiap3 & 5112 & Protein coding & BAI1-associated protein 3 \\
\hline ENSMUSG00000073988 & 7.645538 & Ttpa & 3488 & Protein coding & $\begin{array}{l}\text { Tocopherol }(\alpha) \text { transfer } \\
\text { protein }\end{array}$ \\
\hline ENSMUSG00000050520 & 7.092531 & Cldn 8 & 2356 & Protein coding & Claudin 8 \\
\hline ENSMUSG00000030317 & 6.814687 & Timp4 & 5894 & Protein coding & $\begin{array}{l}\text { Tissue inhibitor of } \\
\text { metalloproteinase } 4\end{array}$ \\
\hline ENSMUSG00000036587 & 6.814687 & Fut7 & 2355 & Protein coding & Fucosyltransferase 7 \\
\hline ENSMUSG00000028778 & 6.814687 & Hertr1 & 2608 & Protein coding & $\begin{array}{l}\text { Hypocretin (orexin) } \\
\text { receptor } 1\end{array}$ \\
\hline ENSMUSG00000021553 & 6.814687 & Slc28a3 & 7902 & Protein coding & $\begin{array}{l}\text { Solute carrier family } 28 \\
\text { (sodium-coupled nucleoside } \\
\text { transporter), member } 3\end{array}$ \\
\hline ENSMUSG00000020218 & 6.814687 & Wif1 & 2427 & Protein coding & Wnt inhibitory factor 1 \\
\hline ENSMUSG00000044365 & 5.609282 & $\mathrm{Cxxc} 4$ & 13401 & Protein coding & CXXC finger 4 \\
\hline
\end{tabular}

calcium/calmodulin dependent protein kinase II $\alpha$ (Camk2a), Camk2b, Sfrp4, Wnt16, VANGL planar cell polarity protein 2, Sfrp1, glypican 4, Sfrp2 and phospholipase C $\beta 1$ (data not shown).

Furthermore, out of the 33 differentially expressed genes in the MAPK signaling pathway, 11 were upregulated in the RF-1 group compared with in the control group, including fibroblast growth factor receptor 2, Ras protein specific guanine nucleotide releasing factor 1 (Rasgrf1), Mapk13, calcium voltage-gated channel subunit $\alpha 1 \mathrm{H}$ (Cacnalh), fibroblast growth factor 10 (Fgf10), growth arrest and DNA damage inducible $\beta$ (Gadd45b), neurotrophin 5, JunD proto-oncogene AP-1 transcription factor subunit, KIT proto-oncogene receptor tyrosine kinase, dual specificity phosphatase 7 (Dusp7) and nerve growth factor receptor, whereas 22 were downregulated, including Cacng6, Pla2g4e, Cacna1s, Cacng1, Cacna2d1, insulin like growth factor 1, angiopoietin 1, Fgf18, myocyte enhancer factor 2C, Fgf7, TEK receptor tyrosine kinase, Gadd45a, MDS1 and EVI1 complex locus, Vegfd, Cacnb1, interleukin 1 receptor type 1, platelet derived growth factor D (Pdgfd), RAS guanyl releasing protein 3 , transforming growth factor $\beta$ receptor 2 ), Dusp8, Pdgf receptor $\alpha$ and ribosomal protein S6 kinase A2 (data not shown).

Expression levels of $I L-1 \beta, I L-6, T N F \alpha, V E G F R$ and VEGF in mice tumor tissues. The expression levels of IL-1 $\beta$, IL-6, TNF $\alpha$, VEGFR and VEGF in the blank control group, positive control group and RF-1 group were detected using ELISA kits. The expression levels of IL-1 $\beta$, IL-6, VEGFR and VEGF in the RF-1 group were significantly downregulated compared with those in the control group $(\mathrm{P}<0.01$; Fig. 5).

\section{Discussion}

The WNT signaling pathway serves an important role in cell growth, differentiation and apoptosis through classical and non-classical signaling pathways, particularly in its state of abnormal activation in tumor tissues (40). In the canonical pathway, the WNT ligand binds to the Frizzled receptor, and the signal is transmitted to the glycogen synthase kinase 3 (GSK-3)/ $\beta$-Axin-adenomatosis polyposis coli complex, which leads to the accumulation of $\beta$-catenin in the cytoplasm and subsequently in the nucleus, resulting in the expression of the lymphoid enhancer-binding factor/T-cell factor-related transcription factors, such as cyclinD1 and c-myc (41). RF-1 increased Wif 1 expression in the present study. As a secretory antagonist of the WNT signaling pathway, Wif1 can compete with the WNT ligand to bind to the Frizzled receptor and block the WNT signaling pathway (42). The increase in Cccx4 expression in the RF-1 group in the present study may inhibit the formation of the complex of DVL1 and Axin by binding to the PDZ region of DVL1, which leads to the continuous phosphorylation of $\beta$-catenin in the cytoplasm and makes it difficult to accumulate, thus blocking the activation of the WNT/ $\beta$-catenin signaling pathway (43).

The MEK/ERK-associated intracellular signal transduction pathway is considered to be a classical MAPK signal transduction pathway, which serves a key role in tumorigenesis and metastasis (44). Cacna2d1 is a member of the family of $\alpha-2 / \delta$ subunits and serves important physiological functions, such as contraction, secretion and nerve transmission, by mediating $\mathrm{Ca}^{2+}$ into a polarized state (45). In the present study, Cacna $2 \mathrm{~d} 1$ expression was downregulated in the RF-1 group. Cacna2d1 expression may affect the state of $\mathrm{Ca}^{2+}$ and further increase the expression 
Table VII. Differentially expressed (downregulated) genes between the blank control group and the Ramaria flaccida (Fr.) Quél. polysaccharide group ( $\log _{2}$ fold-changel>6.9).

\begin{tabular}{|c|c|c|c|c|c|}
\hline Gene ID & $\log _{2}$ fold-change & Gene name & Gene length, bp & Gene biotype & Gene description \\
\hline ENSMUSG00000053093 & 9.972783629 & Myh7 & 8586 & Protein coding & $\begin{array}{l}\text { Myosin, heavy polypeptide } 7 \text {, } \\
\text { cardiac muscle, } \beta\end{array}$ \\
\hline ENSMUSG00000013936 & 8.915444458 & Myl2 & 1950 & Protein coding & $\begin{array}{l}\text { Myosin, light polypeptide } 2 \text {, } \\
\text { regulatory, cardiac, slow }\end{array}$ \\
\hline ENSMUSG00000033196 & 8.800023105 & Myh2 & 7137 & Protein coding & $\begin{array}{l}\text { Myosin, heavy polypeptide } 2 \text {, } \\
\text { skeletal muscle, adult }\end{array}$ \\
\hline ENSMUSG00000059741 & 8.653007497 & Myl3 & 2044 & Protein coding & Myosin, light polypeptide 3 \\
\hline ENSMUSG00000076672 & 8.295564025 & Ighv3-6 & 350 & IG V gene & $\begin{array}{l}\text { Immunoglobulin heavy } \\
\text { variable 3-6 }\end{array}$ \\
\hline ENSMUSG00000078815 & 8.219863343 & Cacng6 & 1977 & Protein coding & $\begin{array}{l}\text { Calcium channel, } \\
\text { voltage-dependent, } \gamma \\
\text { subunit } 6\end{array}$ \\
\hline ENSMUSG00000079055 & 8.180469388 & Slc8a3 & 5332 & Protein coding & $\begin{array}{l}\text { Solute carrier family } 8 \\
\text { (sodium/calcium exchanger), } \\
\text { member } 3\end{array}$ \\
\hline ENSMUSG00000040612 & 7.965542551 & Ildr2 & 8251 & Protein coding & $\begin{array}{l}\text { Immunoglobulin-like domain } \\
\text { containing receptor } 2\end{array}$ \\
\hline ENSMUSG00000045776 & 7.819319431 & Lrtm1 & 7939 & Protein coding & $\begin{array}{l}\text { Leucine-rich repeats and } \\
\text { transmembrane domains } 1\end{array}$ \\
\hline ENSMUSG00000093896 & 7.536914365 & Ighv1-76 & 368 & IG V gene & $\begin{array}{l}\text { Immunoglobulin heavy } \\
\text { variable } 1-76\end{array}$ \\
\hline ENSMUSG00000031343 & 7.473137098 & Gabra3 & 3924 & Protein coding & $\begin{array}{l}\gamma \text {-aminobutyric acid A } \\
\text { receptor, subunit } \alpha 3\end{array}$ \\
\hline ENSMUSG00000096638 & 7.336445309 & Ighv2-9 & 362 & IG V gene & $\begin{array}{l}\text { Immunoglobulin heavy } \\
\text { variable } 2-9\end{array}$ \\
\hline ENSMUSG00000096074 & 7.103554472 & Ighv1-72 & 396 & IG V gene & $\begin{array}{l}\text { Immunoglobulin heavy } \\
\text { variable } 1-72\end{array}$ \\
\hline ENSMUSG00000050211 & 6.924380268 & Pla2g4e & 6960 & Protein coding & Phospholipase A2, group IVE \\
\hline ENSMUSG00000076583 & 6.924380268 & Igkv8-24 & 365 & IG V gene & $\begin{array}{l}\text { Immunoglobulin } \kappa \text { chain } \\
\text { variable } 8-24\end{array}$ \\
\hline
\end{tabular}

A

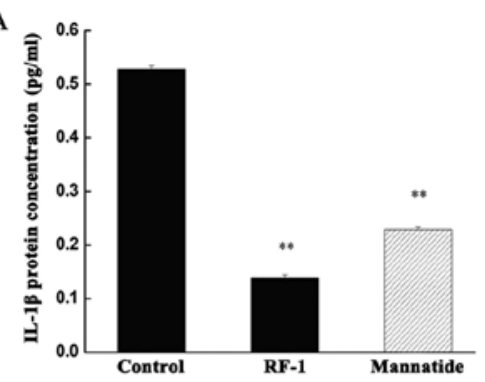

D

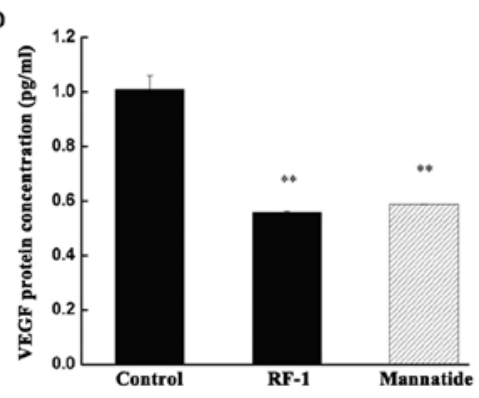

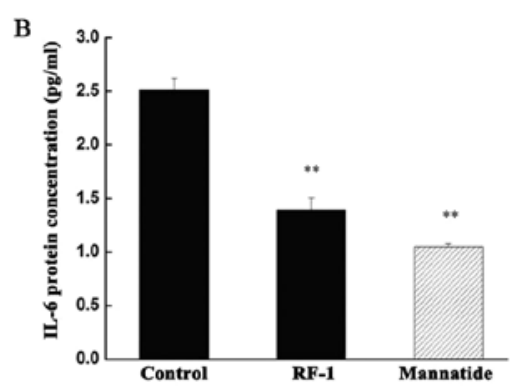
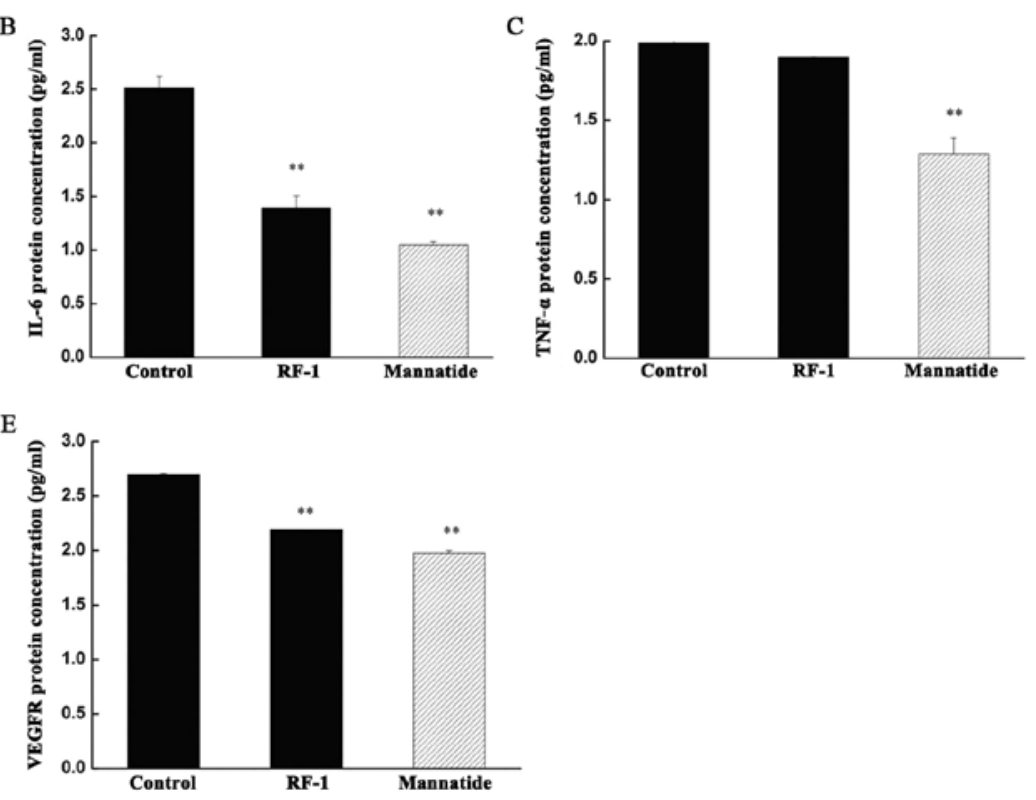

Figure 5. Effect of RF-1 on the protein levels of (A) IL-1 1 , (B) IL-6, (C) TNF $\alpha$, (D) VEGF and (E) VEGFR in tumor tissues. ** P<0.01 vs. control group. IL, interleukin; TNF, tumor necrosis factor; VEGFR, vascular endothelial growth factor receptor; RF-1, Ramaria flaccida (Fr.) Quél. Polysaccharide. 
of Ras protein specific guanine nucleotide releasing factor 1 (RASGRF1) (46). RASGRF1 can directly bind to Cdc42, inhibiting the binding of $\mathrm{Cdc} 42$ with other guanosine exchange factors, and thus preventing the activation of $\mathrm{Cdc} 42$, and inhibiting the invasion and transformation of cancer cells mediated by $\mathrm{Cdc} 42$ (46). The higher the expression levels of RASGRF1, the stronger the anticancer effect and the lower the risk of cancer growth (47).

In addition, phospholipase A2 (PLA2) represents a large group of enzymes that can hydrolyze the structure and function of Sn-2 lipid bonds; it is secreted and released by activated monocytes, macrophages and neutrophils (48). In particular, cytoplasmic PLA2 (cPLA2) serves a key role in the network regulation of the expression and activation of a number of inflammatory mediators (49). Stimulation of PLA2 expression may serve an important role in reversing malignant phenotypes and in the treatment of cancer. Therefore, the decrease of cPLA2 in the RF-1 group suggests that RF-1 may have anti-inflammatory and antitumor effects. The results of the present study can fully explain the mechanism of the antitumor effect of RF-1.

Finally, IL-1 $\beta$ and IL- 6 are important proinflammatory cytokines in inflammatory response $(50,51)$. The expression levels of both cytokines can be used as an index to judge the severity of disease. The expression levels of IL-1 $\beta$ and IL-6 in the RF-1 group were downregulated compared with those in the control group, which indicated that RF-1 may inhibit inflammatory injury in tumor tissues and decrease the levels of IL-1 $\beta$ and IL- 6 . Neovascularization is an important structural basis for the growth, invasion and metastasis of solid tumors. VEGF mainly binds to VEGFR to activate downstream signaling pathways and promote the growth of tumor vessels. The expression levels of VEGF and VEGFR were downregulated in the RF-1 group, which indicated that RF-1 may have anti-angiogenesis effects on tumors and may therefore inhibit the proliferation of tumor cells.

The polysaccharide from Ramaria flaccida (Fr.) Quél. was a homogeneous polysaccharide composed mainly of glucose and galactose with a ratio of $2: 1$, and was named RF-1. The main chain of RF-1 consisted of $(1 \rightarrow 6,2)$ $\alpha$-D-galactopyranose and $(1 \rightarrow 6,4)$ - $\alpha$-D-glucopyranose. One of the branched chains was linked to $4-\mathrm{O}$ of the main glucose chain by $(1 \rightarrow 6)-\alpha$-D-glucopyranose and next linked by one $(\rightarrow 4)-\beta$-D-glucopyranose. The other two branched chains were both linked to $2-\mathrm{O}$ of the main glucose chain by one $(\rightarrow 4)-\beta$-D-glucopyranose. RF-1 inhibited the growth of S180 tumors in vivo. Using $20 \mathrm{mg} / \mathrm{kg} \mathrm{RF}-1$, the inhibition rate of mice $\mathrm{S} 180$ tumors was $48.4 \%$. Compared with the blank control group, 1,971 differentially expressed genes were identified, of which 818 were upregulated and 1,153 were downregulated in the RF-1 group. KEGG pathway enrichment analysis revealed that the WNT and MAPK signaling pathways were significantly enriched. The numbers of differentially annotated genes in these two pathways were 19 and 33, respectively. Additionally, ELISA results revealed that the expression levels of IL-1 $\beta$, IL-6, VEGFR and VEGF were significantly downregulated in the RF-1 group compared with the blank control group. The results of the present study provided a foundation for a deeper investigation of the antitumor effect and mechanism of Ramaria flaccida (Fr.) Quél. polysaccharides and a theoretical basis for the research and development of the economic value of Ramaria flaccida (Fr.) Quél.

\section{Acknowledgements}

Not applicable.

\section{Funding}

The present study was supported by the Science and Technology Support Project of Sichuan Province (grant nos. 2018JY0087 and 2018NZ0055), the Cultivate Major Projects of Sichuan Province (grant no. 16CZ0018), Nanchong Science and Technology Bureau of Sichuan Province (grant no. 16YFZJ0043), Talent Program of China West Normal University (grant nos. 17YC328, 17YC136 and 17YC329), National Training Project of China West Normal University (grant no. 17c039) and the Innovative Team Project of China West Normal University (grant no. CXTD2017-3).

\section{Availability of data and materials}

The datasets used and/or analyzed during the current study are available from the corresponding author on reasonable request.

\section{Authors' contributions}

The present study was designed and conceived by $\mathrm{YH}$ and $\mathrm{XD}$. The experimental procedures and data analysis were performed by MD, XD and YH. The manuscript was prepared by all authors, and all authors read and approved the final manuscript.

\section{Ethics approval and consent to participate}

The animal experiments were conducted according to the Guidelines for Animal Experimentation of the North Sichuan Medical College of China, which were revised according to the Regulations on the Administration of Experimental Animals of the People's Republic of China (decree no. The Second Commission of the People's Republic of China of Science and Technology Commission). The experimental protocols were approved by the North Sichuan Medical College of China (Nanchong, China; approval no. 20180622).

\section{Patient consent for publication}

Not applicable.

\section{Competing interests}

The authors declare that they have no competing interests.

\section{References}

1. Yang H, Guo S and Sagitov A: The collection and separation of the special edible and medicinal mushrooms in china and Kazakhstan and efficacy evaluation. Sci Tech Infor Dev Economy 23: 132-136, 2013. 
2. Zheng L, Chen XQ and Cheong KL: Current trends in marine algae polysaccharides: The digestive tract, microbial catabolism, and prebiotic potential. Int J Biol Macromol 151: 344-354, 2020.

3. Liu L, Cui Y, Pi F, Cheng Y, Guo Y and Qian H: Extraction, purification, structural characteristics, biological activities and pharmacological applications of acemannan, a polysaccharide from aloe Vera: A review. Molecules 24: 1554, 2019

4. Ding X, Hou YL and Hou WR: Structure feature and antitumor activity of a novel polysaccharide isolated from Lactarius deliciosus Gray. Carbohydr Polym 89: 397-402, 2012.

5. Yu Y, Shen MY, Song QQ and Xie JH: Biological activities and pharmaceutical applications of polysaccharide from natural resources: A review. Carbohydr Polym 183: 91-101, 2018.

6. Chen Q, Cao M, Xiang WL, Sun Q, Zhang J, Hou RT, Yan ZY, Yang ZR, Liu J and Zhao J: Study on genes with altered expression in alpha-amanitin poisoned mice and evaluation antagonistic effects of traditional Chinese medicines against its toxicity. Acta Biol Hung 60: 281-291, 2009.

7. Hou YL, Liu L, Ding X, Zhao DQ and Hou WR: Structure elucidation, proliferation effect on macrophage and its mechanism of a new heteropolysaccharide from Lactarius deliciosus Gray. Carbohydr Polym 152: 648-657, 2016.

8. Zhang X, Aweya JJ, Huang ZX, Kang ZY, Bai ZH, Li KH, He XT, Liu Y, Chen XQ and Cheong KL: In vitro fermentation of Gracilaria lemaneiformis sulfated polysaccharides and its agaro-oligosaccharides by human fecal inocula and its impact on microbiota. Carbohydr Polym 234: 115894, 2020.

9. Song G and Du Q: Structure characterization and antitumor activity of an $\alpha \beta$-glucan polysaccharide from auricularia polytricha. Food Res Int 45: 381-387, 2012.

10. Kumar S and Gautam N: Chemical and bioactive profiling, and biological activities of coral fungi from northwestern Himalayas. Sci Rep 7: 46570, 2017.

11. Su S, Yang Q and Li C: Parameter optimization of extraction technology of polysaccharides from Ramaria flaccida. Nat Prod Res Dev 23: 751-754, 2011.

12. Li H, Dou X and Lu Q: Optimization of selected parameters affecting the extraction of DPPH radical-scavenging polysaccharide from Ramaria botrytis fruit bodies. Acta Edulis Fungi 19 69-72, 2012.

13. Ruthes AC, Smiderle FR and Iacomini M: D-glucans from edible mushrooms: A review on the extraction, purification and chemical characterization approaches. Carbohydr Polym 117: 753-761, 2015.

14. Bin Y, Ying Y, Xuefei W, Yanqing HU, Linlin F and Dandan L: Optimization of deproteinized process from echinops latifolius tausch polysaccharide by response surface methodology. Sci Technol Food Industry 35: 287-291, 2014.

15. Plancot B, Gügi B, Mollet JC, Loutelier-Bourhis C, Ramasandra GS, Lerouge P, Follet-Gueye ML, Vicré M, Alfonso C, Nguema-Ona E, et al: Desiccation tolerance in plants: Structural characterization of the cell wall hemicellulosic polysaccharides in three Selaginella species. Carbohydr Polym 208: 180-190, 2019

16. Pandya U, Dhuldhaj U and Sahay NS: Bioactive mushroom polysaccharides as antitumor: An overview. Nat Prod Res 33: 2668-2680, 2019.

17. Mohan M, Achary A, Mani V, Cicinskas E, Kalitnik AA and Khotimchenko M: Purification and characterization of fucose-containing sulphated polysaccharides from Sargassum tenerrimum and their biological activity. J App Phycol 1: 1-13, 2019.

18. Mannino MR and Orecchio S: Polycyclic aromatic hydrocarbons (PAHs) in indoor dust matter of Palermo (Italy) area: Extraction, GC-MS analysis, distribution and sources. Atmospheric Environment 42: 1801-1817, 2008

19. Sathivel A, Raghavendran HB, Srinivasan $P$ and Devaki T: Anti-peroxidative and anti-hyperlipidemic nature of Ulva lactuca crude polysaccharide on D-Galactosamine induced hepatitis in rats. Food Chem Toxicol 46: 3262-3267, 2008

20. Šilhánek J: Comparisons of the most important chemistry databases-Scifinder program and reaxys database system. Chemicke Listy 108: 81-106, 2014.

21. Gao B and Yang GZ: Effects of Ganoderma applanatum polysaccharide on cellular and humoral immunity in normal and sarcoma 180 transplanted mice. Phytotherapy Res 5: 134-138, 1991.

22. Duan DP, Dang XQ, Wang KZ, Wang YP, Zhang H and You WL: The cyclooxygenase-2 inhibitor NS-398 inhibits proliferation and induces apoptosis in human osteosarcoma cells via downregulation of the survivin pathway. Oncol Rep 28: 1693-1700, 2012 .
23. Parkhomchuk D, Borodina T, Amstislavskiy V, Banaru M, Hallen L, Krobitsch S, Lehrach H and Soldatov A: Transcriptome analysis by strand-specific sequencing of complementary DNA. Nucleic Acids Res 37: e123, 2009.

24. Daehwan K, Ben L and Steven LS: HISAT: A fast spliced aligner with low memory requirements. Nat Methods 12: 357-360, 2015.

25. Trapnell C, Roberts A, Goff L, Pertea G, Kim D, Kelley DR, Pimentel H, Salzberg SL, Rinn JL and Pachter L: Differential gene and transcript expression analysis of RNA-seq experiments with TopHat and Cufflinks. Nat Protoc 7: 562-578, 2012.

26. Anders S and Huber W: Differential expression analysis for sequence count data. Genome Biol 11: R106, 2010.

27. Gao X, Wang $\mathbf{J}$ and Zhang S: Integrated bioinformatics analysis of Hub genes and pathways in anaplastic thyroid carcinomas. Int J Endocrinol 2019: 9651380, 2019.

28. Kanehisa M and Goto S: KEGG: Kyoto encyclopedia of genes and genomes. Nucleic Acids Res 28: 27-30, 2000.

29. Robinson MD, McCarthy DJ and Smyth GK: edgeR: A Bioconductor package for differential expression analysis of digital gene expression data. Bioinformatics 26: 139-140, 2010.

30. Martineau E, Khantache KE, Pupier M, Sepulcric P, Akoka S and Giraudeau P: Non-linear effects in quantitative 2D NMR of polysaccharides: Pitfalls and how to avoid them. J Pharm Biomed Anal 108: 78-85, 2015.

31. Jahanbin K, Abbasian A and Ahang M: Isolation, purification and structural characterization of a new water-soluble polysaccharide from Eremurus stenophyllus (boiss. \& buhse) baker roots. Carbohydrate Polymers 178: 386-393, 2017.

32. Santos G, Oliveira ES, Pinheiro ADN, da Costa PM, de Freitas JCC, de Araújo Santos FG, Maia FMM, de Morais SM and Nunes-Pinheiro DCS: Himatanthus drasticus (Apocynaceae) latex reduces oxidative stress and modulates $\mathrm{CD} 4^{+}, \mathrm{CD} 8^{+}$, FoxP $3^{+}$and HSP $-60^{+}$expressions in Sarcoma 180-bearing mice. J Ethnopharmacol 220: 159-168, 2018.

33. David B, Edward H, Nick A, Takeshi K, Udo O, Simon H, Daniel S, Dietrich L, John A and Hassan AB: A germline mutation of CDKN2A and a novel RPLP1-C19MC fusion detected in a rare melanotic neuroectodermal tumor of infancy: A case report. BMC Cancer 16: 629-639, 2016.

34. Derenzini M, Montanaro L and Trerè D: Ribosome biogenesis and cancer. Acta Histochem 119: 190-197, 2017.

35. Michael GK, Jill AI, Smrithi MP, Alex SC and Vassie CW: RpL22e, but not RpL22e-like-PA, is SUMOylated and localizes to the nucleoplasm of Drosophila meiotic spermatocytes. Nucleus 4: 241-258, 2013.

36. Shimomura T, Kawakami M, Tatsumi K, Tanaka T, Morita-Takemura S, Kirita T and Wanaka A: The role of the Wnt signaling pathway in upper jaw development of chick embryo. Acta Histochem Cytochem 52: 19-26, 2019.

37. Young BK, Boh-Ram K, Kyungsil Y, Choi EK, Seo SH, Yeonah L, Min AL, Jung BY, Mi SP and Seung BR: WIF1 can effectively co-regulate pro-apoptotic activity through the combination with DKK1. Cell Signal 26: 2562-2572, 2014.

38. Li C, Wang Z, Chen S, Zhang J, Qu K and Liu C: MicroRNA-552 promotes hepatocellular carcinoma progression by downregulating WIF1. Int J Mol Med 42: 3309-3317, 2018.

39. Kojima T, Shimazui T, Hinotsu S, Joraku A, Oikawa T, Kawai K, Horie R, Suzuki H, Nagashima R, Yoshikawa K, et al: Decreased expression of CXXC4 promotes a malignant phenotype in renal cell carcinoma by activating Wnt signaling. Oncogene 28: 297-305, 2009.

40. Chiurillo M: Role of the Wnt/ $\beta$-catenin pathway in gastric cancer: An in-depth literature review. World J Exp Med 5: 84-102, 2015.

41. Hino S, Kishida S, Michiue T, Fukui A, Sakamoto I, Takada S, Asashima $M$ and Kikuchi A: Inhibition of the Wnt signaling pathway by Idax, a novel Dvl-binding protein. Mol Cell Biol 21: 330-342, 2001

42. Wissmann C, Wild PJ, Kaiser S, Roepcke S, Stoehr R, Woenckhaus M, Kristiansen G, Hsieh JC, Hofstaedter F, Hartmann A, et al: WIF1, a component of the Wnt pathway, is down-regulated in prostate, breast, lung, and bladder cancer. J Pathol 201: 204-212, 2003.

43. White JJ, Mazzeu JF, Coban-Akdemir Z, Bayram Y, Bahrambeigi V, Hoischen A, van Bon BWM, Gezdirici A, Gulec EY, Ramond F, et al: WNT signaling perturbations underlie the genetic heterogeneity of Robinow syndrome. Am J Hum Genet 102: 27-43, 2018.

44. Zhang T, Chen H, Zhou Y, Dong W, Cai H and Tan W: Cooperation of FGF/MEK/ERK and Wnt/ $\beta$-catenin pathway regulators to promote the proliferation and pluripotency of mouse embryonic stem cells in serum- and feeder-free conditions. Bioresources Bioprocessing 6: 12, 2019. 
45. Dolphin AC: Calcium channel auxiliary $\alpha-2 / \delta$ and $\beta$ subunits: Trafficking and one step beyond. Nat Rev Neurosci 13: 542-555, 2012.

46. Fernando C, Victoria S, Lorena A, Fredrik W, Erik S, Christopher JM and Piero C: RasGRF suppresses Cdc42-mediated tumour cell movement, cytoskeletal dynamics and transformation. Nat Cell Bio 13: 819-826, 2011.

47. Elena S, David M, Michela S, Romilde M, Maria S, Rita G, Andrea M, Silvio T, Lilia A and Marco V: Novel RasGRF1-derived Tat-fused peptides inhibiting Ras-dependent proliferation and migration in mouse and human cancer cells. Biotechnol Adv 30 233-243, 2012.

48. James DC, Lin LL, Ronald WK and Clark JD: A novel arachidonic acid-selective cytosolic PLA2 contains a $\mathrm{Ca}^{2+}$-dependent translocation domain with homology to PKC and GAP. Cell 65 1043-1051, 1991
49. Faure G, Corringer PJ and Edelman A: Therapeutic potential of rattlesnake PLA2: Impact in Cystic Fibrosis. Toxicon 149: 93-94, 2018.

50. Jaworska J and Janowski T: Expression of proinflammatory cytokines IL-1 $\beta$, IL- 6 and TNF $\alpha$ in the retained placenta of mares. Theriogenology 126: 1-7, 2018.

51. Rostami H and Gharibzahedi S: Cellulase-assisted extraction of polysaccharides from Malva sylvestris: Process optimization and potential functionalities. Int J Biol Macromol 101: 196-206, 2017.

cc) (i) () $($ This work is licensed under a Creative Commons cc) International (CC BY-NC-ND 4.0) License. 